\title{
Accessing Multimedia Technology and Listening Skill: Are they correlated?
}

\author{
Dewi Yana ${ }^{1)}$, Aulia Putri ${ }^{2)}$ \\ ${ }^{1)}$ Universitas Negeri Padang, ${ }^{2}$ Universitas Riau Kepulauan \\ email: alifdewi1982@gmail.com¹, aulia@fkip.unrika.ac.id ${ }^{2}$
}

\begin{abstract}
People's lives are affected by several aspects of Information, Communication, and Technology, and multimedia technology is one of them. Then, Junior-senior-higher students today are identified as generation Z; they are characterized by the first digital generation who love to access the internet. This paper presents the correlation between students' intensity of accessing multimedia technology products via the internet toward their listening skills. This study applies a quantitative method with a correlational design. The population is the first year's students of the English Education Study Program of UNRIKA which applies the total sampling technique. The research data were gathered from an online questionnaire and listening test. The data were analyzed with descriptive statistics- Pearson correlation employing SPSS to determine the correlation between; students' intensity of accessing multimedia technology (MT) products through the internet and listening skill. The result found that there is a moderate and negative correlation between the two variables (the Pearson correlation value is $-0.252>0.05$ ). There are some possible factors considered to the finding; it implies seeking further truth of the factors considered.
\end{abstract}

Keywords: Multimedia Technology, Listening Skill, Z-Generation

\section{Introduction}

As a result of the fast ICT change, there is a corresponding type of generation emerged. This generation has a different profile compared to previous generations because they are true digital natives, which is popularly called as Z generation (Hernandez-de-Menendez, Díaz \& Morales-Menendez, 2020). They have always had access to the Internet (Prensky, 2001; Dolot, 2018). Their identity is defined by technology and the social web, and they were born in the age of social media (Singh, \& Dangmei, 2016). All of the gadgets and tools of the digital age have always been accessible to them (Prensky, 2001). Besides being comfortable with computers and the Internet, they also are hyper-connected (Marshall \& Wolanskyj-Spinner, 2020). With this condition, the $\mathrm{Z}$ generation can access all the information from anywhere at any time, without losing any data. (Ganascia, 2015). That is how Generation $\mathrm{Z}$ appears in line with technological developments in the 21 st century.

Next, since acknowledged that English is the language used to spread information (Flammia, M., \& Saunders, 2007), and being the most (25,9\%) used language on the internet (https://www.statista.com); it provides a good opportunity for the current EFL students. The students can expose English-language information presented on the internet with various multimedia technology products.Multimedia products which are meant in the form of online videos on YouTube, podcasts, animations, images, text, and interactivity, etc (Smith, 2021)

Those conditions above offer challenges to the teachers of English. They can take advantage of multimedia applications to bring new activities in the classroom, as well as a new path for teachers to explore their creativity and curiosity (Guan, Song, \& Li, 2018). However, they also need to consider their 
students' experiences. Because Dewey (2007) emphasizes experience is a basis for education. Hence, the intensity or how often students interact with objects of their interest certainly increase their experience. The students' experience is crucial to be acknowledged as a barometer for teachers to maximize their role as a facilitator who embeds technology according to the needs of their students (cited in https://www.tribalgroup.com).

Related studies in terms of advantaging multimedia to enhance English language teaching and learning have been published, such as Guan \& Li (2018), Aljazzaf (2020); An, \& Zhang (2021); and Chen, (2021). However, these studies focused to examine the impact of computer multimedia; the importance of multimedia; the application of computer multimedia technology; and the influence of multimedia in enhancing English skills or English teaching. Meanwhile, the study of students 'experience intensity in accessing information toward multimedia technology products via the internet is still limited.

In communication, four aspects enhance a person's language abilities: listening, speaking, writing, and reading. Listening is the first element introduced in one's life. It is the 'Cinderella skill', this term is used because listening skill is often neglected in a research area as it is considered as passive skill (Nunan in Solak, 2016). Moreover, it is the basic skill in understanding a native speaker in a normal speed (Chastain in Gilakjani \& Sabouri, 2016). Therefore, it is then become interesting to study:How are the EFL Gen Z students' intensity in accessing the internet? Do they access the internet in the English language? Is there a relationship between students' intensity in accessing multimedia technology products and their English skills?

\section{Methods}

This research is quantitative research with a correlational design. It aims to determine the correlation between students' intensity of accessing multimedia technology products via the internet toward their listening skill. This study used a population of the 1st-semester students of the English Education Study Program, University of Riau Kepulauan, in which the sample was selected by total sampling technique. Data were collected by using an online questionnaire and listening test in November 2021. The questionnaire was in the form of the four Likert Scales about the intensity of students in accessing digital multimedia products via the internet. There were 16 products in question inspired by Smith and the team alluded to in their research (Smith, Pacheco, \& Khorosheva, 2021). While the listening test is in the form of Paper-Based TOEIC taken from Educational Testing Service (ETS) to determine the ability of students' listening skill. Test takers listen to a variety of questions and short conversations recorded in English, then answer questions based on what they have heard (100 items total). There are four parts to this test; Part 1: Photographs, Part 2: Question-Response, Part 3: Conversations, and Part 4: Short Talks. The data were analyzed with descriptive statistics-Pearson correlation employing SPSS to determine the correlation between the two variables; students' intensity of accessing multimedia technology products through the internet and listening skill.

\section{Results and Discussion}

As a first step towards hypothesis testing, we conducted a normality test to determine whether the research data were normally distributed. The Shapiro-Wilk test was used because the sample was less than 30 . The results of this normality test were as follows:

Table 1. NormalityTest

\begin{tabular}{lr|r|r|r|r|r} 
& \multicolumn{3}{c|}{ Kolmogorov-Smirnov $^{\text {a }}$} & \multicolumn{3}{c}{ Shapiro-Wilk } \\
& Statistic & \multicolumn{1}{c}{ df } & \multicolumn{1}{c|}{ Sig. } & Statistic & \multicolumn{1}{c}{ df } & \multicolumn{1}{c}{ Sig. } \\
\hline MT Accessing Intensity & .160 & 29 & .055 & .942 & 29 & .113 \\
\hline Listening skill & .083 & 29 & $.200^{*}$ & .968 & 29 & .495 \\
\hline
\end{tabular}


Based on the results of the normality test on the table above, it is known that the significance value for Multimedia Technology (MT) accessing intensity was 0.113 , it is more than 0.05 , and for Listening is 0.495 also higher than 0.05 so it can be concluded that the residual value is normally distributed.

Afterward, the next hypothesis can be investigated to find out whether there is an association between two variables, Multimedia Technology accessing intensity and Listening skill. In this study, a Pearson Product Moment Correlation was conducted. The results are as follows:

Table 2. Correlations

\begin{tabular}{llrr}
\hline & & \multicolumn{1}{c}{ MT } \\
& & $\begin{array}{c}\text { Listening } \\
\text { Accessing } \\
\text { Intensity }\end{array}$ & \\
MT & Pearson Correlation & 1 & -.252 \\
Accessing & Sig. (2-tailed) & & .187 \\
Intensity & $\mathrm{N}$ & 29 & 29 \\
Listening & Pearson Correlation & -.252 & 1 \\
skill & Sig. (2-tailed) & .187 & \\
& $\mathrm{~N}$ & 29 & 29 \\
\hline
\end{tabular}

Based on the table above, it is surprising to see that the Pearson correlation value between MT accessing intensity and listening is -0.252 , meaning that there is a negative relationship between MT accessing intensity students listening skills, and it shows moderate level. It is out of the researchers' prediction, and the fact is the students' intensities in accessing the information on the internet is contradictory to their listening skills.

This happens because of some possible considerations. First, generally, students have not accessed MT which is in English. This can be proven from the response to the questionnaire they gave that 53.3\% of students always access the internet, but only $10 \%$ of them always access the English-language information on the internet. It means that although current EFLZ-generation students always access information through various multimedia available on the internet, most of them have not used English texts. In addition, this may also happen because the students do not understand the listening process well. As Ampa (2015) notes that during the listening process, receivers must hear the text, understand it, retain information, integrate information with what follows, and continually adjust what they hear based on prior knowledge and incoming information. (Ampa, 2015). Then, the third possible reason is it is not enough to have good hardware such as multimedia technology; it should also have good software, which is the cooperation of teacher and student (Chen, 2021). Those reasons probably become the factors why students' intensity in accessing multimedia via the internet be the contrary of their listening skills.

As a result of this research finding and the three possible factors, teachers need to stimulate students' habits or intensity in accessing the internet to find information in English text. They also need to take advantage of multimedia products spread on the internet as authentic learning media to train students in understanding the listening process with good collaboration between teacher and students; otherwise, the presence of the multimedia will not be beneficial. This is in line with Guan (2018) who notes teachers and students alike have appreciated the distinctive teaching characteristics and classroom environment for helping students in improving their English learning abilities (Guan, 2018). 
Moreover, to maximize the use of Multimedia in learning English, it should be highlighted that the existence of sophisticated multimedia systems is ineffective unless they are applied according to the right methodology for delivering the right message to those who explore and apply it (Zin, Sakat, Ahmad, \& Bhari, 2013).Then, An \& Zhang (2021) also emphasize that it is crucial to view Multimedia in English teaching from the correct perspective. Reflecting on this study results and related ideas, it can be implied if students' intensity in accessing multimedia technology products on the internet is directed in increasing access to English texts, and followed with a good learning environment, of course, the two variables discussed in this study may have a positive relationship.

Therefore, as an implication of this research, it is necessary to do further study on factors affecting EFL Z generation students in learning English listening; on how EFL students of Z generation perceive the possibility use digital products on the internet toward listening; on how the possibilities for EFL teachers are to take advantage of authentic digital multimedia available on the internet to promote their English teaching-learning process. The answers of these further studies are needed as a basis for teachers to understand the specific characteristics of gen $\mathrm{Z}$ students regarding the use of digital multimedia products on the internet; to engage their EFL learners and enhance their learners' English listening skill.

Research results should summarize findings rather than merely presenting detailed research data. Do not describe the numbers (tables/graphs) in detail but rather present the findings or trends. Write down the data that has been processed only in the article (in the form of tables or graphs/images but may not be both for the same data). Statistical data and differences can be presented. It should be written objectively and factually and without expressing personal opinion. Do not discuss it first in the RESULTS section. Only present data that supports discussion only. Do not hide data; it could be that novelty comes from data that is omitted. Do not use the location when referring to pictures or tables, for example: "... presented in Figure 1 below," but "... is presented in Figure 1," or "... (Figure 1)." Consistency: All images/tables presented must be referenced in the body of the text, or vice versa referenced in the body of the text must have images/tables. The table caption is above the table. Figure caption is below the image.

\section{Conclusion}

This research is to investigate to understand the EFL Gen Z students' intensity in accessing the internet, to know whether The EFL Gen Z students access the internet in English language or not; and to measure the relationship between students' intensity in accessing multimedia technology products and their English skills? The Result found that that 53.3\% of students always access the internet, but only $10 \%$ of them always access it in the English language. It means that although the current EFL Zgeneration students always access various information through various multimedia available on the internet, most of them have not taken advantage of the English texts available in the various multimedia products spread on the internet. Next, that there is a moderate and negative relationship between MT accessing intensity and students' listening skills. It is out of the researchers' assumption that students' intensities in accessing the information on the internet are positively correlated to their listening skills. There are 3 possible factors consider and, it implies to do further study to seek the truth.

\section{Acknowledgments}

We would like to thank the Head of the English Education Study Program \& the Head of English Laboratory of Teacher Training and Education Faculty, University of Riau Kepulauan Batam who facilitated us in accessing students' data and the English Lab in gathering this research data.

\section{References}

Aljazzaf, Z. (2020). Factors influencing the use of multimedia technologies in teaching the english language in Kuwait. International Journal of Emerging Technologies in Learning (iJET), 15(5), 212-234. 
Ampa, A. T. (2015). The implementation of interactive multimedia learning materials in teaching listening skills. English Language Teaching, 8(12), 56-62.

An, L., \& Zhang, G. (2021). Investigation and reflection on multimedia-assisted english classroom teaching. The International Journal of Electrical Engineering \& Education, doi: 10.1177/002072 0920983708

Chen, M. (2021). Research on the management mode of college english listening teaching under computer multimedia technology. Journal of Physics: Conference Series, vol. 1992, 3, 32-54.

Dewey, J. (2007). Experience and education. Kappa Delta Pi Lecture.

Dolot, A. (2018). The characteristics of generation Z. E-mentor, 74(2), 44-50.

Flammia, M., \& Saunders, C. (2007). Language as power on the internet. Journal of the American Society for Information Science and Technology, 58(12), 1899-1903.

Ganascia, J. G. (2015). Views and examples on hyper-connectivity. Floridi, L. (Eds.) The online manifestobeing human in a hyperconnected era. Singapore: Springer link, pp.65-55

Gilakjani, A. P. \& Sabouri, N. B. (2016). Learners' listening comprehension difficulties in english language learning: A literature review. English Language Teaching, 9(6), 123-133.

Guan, N., Song, J., \& Li, D. (2018). On the advantages of computer multimedia-aided English Teaching. Procedia computer science, 131, 727-732.

Hernandez-de-Menendez, M., Díaz, C. A. E. \& Morales-Menendez, R. (2020). Educational experiences with Generation Z. International Journal on Interactive Design and Manufacturing (IJIDeM), 14(3), 847-859.

Marshall, A. L. \& Wolanskyj-Spinner, A. (2020). COVID-19: Challenges and opportunities for educators and generation Z learners. Mayo Clinic Proceedings, 95(6),1135-1137).

Prensky, M. (2001). Digital natives, digital immigrants. On the Horizon, 9(5), $1-6$.

Singh, A. P. \& Dangmei, J. (2016). Understanding the generation Z: The future workforce. South-Asian Journal of Multidisciplinary Studies, 3(3), 1-5.

Smith, B. E., Pacheco, M. B., \& Khorosheva, M. (2021). Emergent bilingual students and digital multimodal composition: A systematic review of research in secondary classrooms. Reading Research Quarterly, 56(1), 33-52.

Solak, E. (2016). Teaching language skills for prospective english teachers. Ankara: Pelkan.

Trew, G. (2007). Tactics for TOEIC: Listening and reading test. London: Oxford University Press. 
Proceeding of International Conference on Language Pedagogy

Vol. 1. No. 1, pp. 20-25, 2021

ISSN: 2809-4808

DOI: https://doi.org/10.24036/icolp.v1i1.17

Zin, M. Z. M., Sakat, A. A., Ahmad, N. A., \& Bhari, A. (2013). Relationship between the multimedia technology and education in improving learning quality. Procedia-Social and Behavioral Sciences, 90, 351-355. 